\title{
YALAN TANIKLIK SUÇU (TCK m. 272) VE ETKİN PİŞMANLIK
}

\author{
Perjury and Effective Remorse
}

Feyza KIR*

\section{ÖZET}

Ceza muhakemesinin maddi gerçeğin ortaya çıkarılmasına ilişkin amacına ulaştıran en etkili yol, adil yargılanma hakkı temelinde güvenilir ve sahih delillerin temin edilmesidir. Bu bağlamda, tanık beyanı muhakemedeki en önemli delillerden biridir. Hatırlayamamak ya da öyle olduğu zanniyla konuşmak gibi insani sebepler haricinde bilerek, isteyerek, kasten gerçeğin değiştirilerek veya saklanarak ifade edilmesi, halk arasında "yalancı şahitlik" olarak tabir edilen yalan tanıklık suçunu oluşturmaktadır. $\mathrm{Bu}$ suçun ağırlaşmış nitelikli halleri olabileceği gibi, failin cezasının azaltılmasını gerektiren ve hatta şahsi cezasızlık halleri de bulunmaktadır. Yalan ile adalete verilen zararı önlemek veya en aza indirmek için suç sonrasında pişmanlık duyulması hali de etkin pişmanlık hükümlerini gündeme getirmektedir. Bu hususlarla birlikte etkin pişmanlık hükümlerinin Kanunun lafzına itibar ederek sadece aleyhe tanıklıkta uygulanmasını savunan görüşe karşın, bizim de savunucuları arasında yer aldığımız, lehe aleyhe ayırımı yapılmaksızın yalan tanıklıktan pişman olan kişilerin tümüne etkin pişmanlık hükümlerinin uygulanması gerektiği görüşü, yarg1 kararlarındaki değerlendirmeler ile birlikte bu makalede ele alınmaya çalışılmıştır.

Anahtar Kelimeler: Tanık Beyanı, Delil, Yalan Tanıklık, Tanık, Etkin Pişmanlık.

Makalenin Geliş Tarihi: 06.07.2021, Makalenin Kabul Tarihi: 18.08.2021.

Yargitay 16. Ceza Dairesi-Ceza Genel Kurulu Üyesi, (feyzaks@yahoo.com.tr, ORCID: https://orcid.org/0000-0002-6727-3324) 


\begin{abstract}
The most effective way of achieving the goal of criminal procedure for revealing the truth is to provide reliable evidence based on the right to a fair trial. In this regard, the witness testimony is one of the most important evidence. Expressing the case by deliberately changing the truth or hiding it on purpose, apart from humanitarian reasons like not being able to remember or speaking on the assumption, constitutes the crime of perjury, popularly referred to as "false testimony". There may be aggravated cases of this crime, while some other cases that require a reduction in the punishment of the perpetrator or even personal impunity. Feeling remorse after the crime also brings up effective remorse provisions for the purpose of preventing or minimizing the harm caused to justice by perjury. Moreover, despite the view arguing that effective remorse provisions should only apply to testimonies which are in favor considering letter of Law, the view that effective repentance provisions should apply to all those who feel remorse due to their perjury, regardless whether it is against or not, which we also defend, has been tried to be addressed in this article together with the evaluations in judicial decisions.
\end{abstract}

Keywords: Witness Testimony, Evidence, Perjury, Witness, Effective Remorse.

\title{
I. YALAN TANIKLIK SUÇU
}

Hukuk devletinin en önemli fonksiyonlarından biri olan yargılama sürecinin asıl hedefi adaletin yerine getirilmesidir. Teknolojik gelişmelerle birlikte kriminoloji bilimindeki ilerleme ile birlikte bilimsel anlamda iz, emare ve belirtilerin delil değeri daha kesin ve doğrudan sonuca ulaştırır netlikte olmasına rağmen, pek çok muhakeme dalında tanık beyanı hala önemini korumaktadır. Bilindiği gibi ceza muhakemesinde ispat vasıtaları diğer muhakemeler olan özel hukuk muhakemesi ve idare hukuku muhakemesinden farklı olarak önceden hazırlanmaz. Hatta büyük çoğunlukla suçlar gizlilik içinde işlenir ve suç ihbarının alınmasıyla birlikte suçtan geriye kalan belirtiler ve deliller toplanarak muhakeme yürütülür ve sonuca varılır. Buna mukabil ceza muhakemesinin medeni muhakemeden ayrılan en önemli özelliği delil serbestisidir ${ }^{1}$. Dolayısıyla ceza yargılamasının ispat vasıtalarından olan beyan delilleri içinde yer alan tanık beyanı tüm yargılama faaliyetleri açısından müşterek önemli taşımaktadır.

1 CENTEL, Nur/ZAFER, Hamide, Ceza Muhakemesi Hukuku, Beta Yayıncılık, 16. Bask1, İstanbul 2019, s. 7. 
Tanık beyanıyla ilgili genel anlayış kişinin istemeden yalan söylemeyeceği yolundadır. Kişi şahit olduğu bir olayı unutabilir ya da tam hatırlayamayabilirken, gerçekte olmayan bir olayı hatırlamak mümkün değildir. $\mathrm{Bu}$ nedenle Yargitay'ın süregelen uygulamalarında olduğu gibi yalan olduğu kesinleşmemiş tanık beyanına itibar edilmelidir. Bu nedenle de tanık dinlemeye yetkili makamlar önünde alınan yeminiyle (CMK m. 54, m. 55) beyanına başvurulan kişinin doğruları söylemesi zorunludur. Aksi halde kasten doğruları söylemeyen kişi için "yalan tanıklık" suçu oluşur.

Kamu düzeni kişileri doğruya yönlendirmek için ceza tehdidi ile suç düzenlemesi yapmakla birlikte, kişilerin bazı yakınları hakkında tanıklıktan da çekinme hakkını (CMK m. 45, 46, 48) tanımaktadır. Burada da kişilerin yakınlarına yönelik sadakat duyguları ile ceza tehdidi arasında kalmamaları, ikilem yaşamamaları amaçlanmışıır ${ }^{2}$. Nitekim Anayasamızın 38. maddesinde yer alan "hiç kimse kendisi ve kanunda gösterilen yakınlarını suçlayıcı beyanda bulunmaya zorlanamaz" hükmünün bir gereği olarak kişilere kanunda sayılan yakınları hakkında tanıklıktan ve yeminden çekinme hakkı tanınmaktadır ${ }^{3}$.

Ceza Muhakemesi Kanununun 52. maddesi düzenlemesi ile de tanıkların ayrı ayrı ve yanlarında diğer tanıklar olmaksızın dinlenilmesi esastır. Burada da tanıkların birbirlerinin beyanlarından etkilenmemesi amaçlanmaktadır. CMK'nın 59. maddesinde de tanık ifade verirken onu dinlemenin usulü düzenlenmiştir. Tanık sözü kesilmeden dinlenilmeli, araya girip soru yöneltilmemeli, bildiğini sağlıklı bir şekilde aktarması için imkan ve firsat verilmelidir. Böylece etkiden uzak saf beyanın elde edilmesi amaçlanmaktadır. Zira tanığa müdahale beyanın içeriğini etkilemektedir ${ }^{4}$. Tanığın beyanı bittikten sonra yargılama süjeleri Cumhuriyet savcısı, müdafi veya vekil sıfatıyla duruşmaya katılan avukat, duruşma disiplinine uygun olarak tanı̆ga doğrudan soru sorabilirler. Sanık ve katılanın da mahkeme başkanının aracılığı ile tanığa soru sorması mümkündür.

Ceza Muhakemesinde iki mesele karşımıza çıkmaktadır. Biri, olayın kim tarafindan, kime karşı, nerede ve nasıl gerçekleştiğinin tespiti yani sübut meselesi olan maddi mesele iken, diğeri meydana gelen olaya hukuki platformda nasıl isim konulduğu, yani kişinin ihlal ettiği hukuk

2 FEYZİĞLLU, Metin, Ceza Muhakemesi Hukukunda Tanıklık, US-A Yayıncılık, Ankara 1996, s. 197.

3 ÜNVER, Yener/HAKERİ, Hakan, Ceza Muhakemesi Hukuku, Adalet Yayınevi, 17. Bask1, Ankara 2020, s. 253.

4 ÖZBEK, Veli Özer/DOĞAN, Koray/BACAKSIZ, Pınar/TEPE, İlker, Ceza Muhakemesi Hukuku, Seçkin Yayınevi, Ankara 2020, s. 626. 
norm/normlarının neler olduğuna ve failin sorumluluğunun belirlenmesine yönelik hukuki meseledir ${ }^{5}$. Tüm muhakeme dalları için önemli olan maddi gerçeğe kavuşmaktır. Bu da içeriği doğru tanık beyanının maddi meselenin ortaya konulmasında ne kadar gerekli olduğunu göstermektedir.

Muhakemenin konusunu oluşturan maddi meselenin tespiti ancak ispat araçlarıyla mümkündür. Bunlar da geçmişte yaşanmış olan olayı temsil eden ${ }^{6}$ ve olay1 muhakeme süjelerinin gözünde canlandıran delillerdir. Hukuk muhakemesinde ve idari muhakemede genellikle uyuşmazlığın dayanağı olan belge ile idarenin eylem ve işlemlerinin neticesi olan belge delili esastır. Oysa ceza muhakemesinde deliller olaydan sonra aranıp bulunduğu için tanık beyanı ön planda tutulan bir delil niteliğindedir. İspat kurallarındaki farklılığa rağmen tanık beyanı tüm muhakeme türlerinde maddi meselenin çözümünde önemli bir yer $\operatorname{tutar}^{7}$ ve tanıkların doğruları söyleme yükümlülüğü vardır.

Muhakemenin özü olan maddi meselenin ortaya çıkmasını engelleyecek olan ve dolayısıyla hukuki meselenin doğru çözümlenmesini engelleyecek olan "yalan tanıklık" suçu gerek 765 sayılı Türk Ceza Kanununda gerekse 5237 sayılı Türk Ceza Kanununda "Adliyeye Karşı Suçlar" başlığı altında düzenlenmiştir. TCK'nın Özel Hükümlere ait İkinci Kitabının Dördüncü kısmında "Millete ve Devlete Karşı Suçlar" tanımlanmıştır. Bu kısım dokuz bölümden oluşmaktadır ve ikinci bölümünde Kanunun 267 ila 298 maddeleri arasında düzenlenen ve ceza adaletinin gerçekleşmesini engellemeye yönelik fiillerin yaptırım altına alındığı "Adliyeye Karşı Suçlar”a yer verilmiştir.

5237 sayılı TCK'nın 272. maddesine göre;

"Yalan tanıklık

(1) Hukuka aykırı bir fiil nedeniyle başlatılan bir soruşturma kapsamında tanık dinlemeye yetkili kişi veya kurul önünde gerçeğe aykırı olarak tanıklı yapan kimseye, dört aydan bir yıla kadar hapis cezasl verilir.

5 ŞAHIN, Cumhur / GÖKTÜRK, Neslihan, Ceza Muhakemesi Hukuku, Seçkin Yayınevi, 5. Bask1, Ankara 2020, s.26, 235.

6 Delil olayı temsil edici olmalıdır. Bundan maksat, ispat aracının olayın bir parçası olması veya olayı yansıtmasıdır. Olayın bir parçasını temsil etmeyen veya olayı aksettirmeyen şey delil değildir. Örneğin olay yerindeki suç aleti olayın bir parçası iken, olaya tanık olan kişinin beyanı ise olayı yansıtan bir delildir. Olayı temsil edicilik, geçmişte yaşanmış olayı anlatabilme ve gözümüzde canlandırabilme yeteneğini ifade etmektedir. Delilin sağlam ve güvenilir olması da olayı temsil ediciliğin bir unsurudur. Bkz. ŞAHIN / GÖKTÜRK, s. 29.

7 GÖKTÜRK, Neslihan, "Yalan Tanıklık Suçu”, Gazi Üniversitesi Hukuk Fakültesi Dergisi, C. XX, Y. 2016, S.1, ss.347-409, s. 349. 
(2) Mahkeme huzurunda ya da yemin ettirerek tanı dinlemeye kanunen yetkili kişi veya kurul önünde gerçeğe aykırı olarak tanıklı yapan kimseye bir yıldan üç ylla kadar hapis cezası verilir.

(3) Ü̧̧ yıldan fazla hapis cezasını gerektiren bir suçun soruşturma veya kovuşturması kapsamında yalan tanıklık yapan kişi hakkında iki yıldan dört yıla kadar hapis cezasına hükmolunur.

(4) Aleyhine tanıklikta bulunulan kişi ile ilgili olarak gözaltına alma ve tutuklama dışında başka bir koruma tedbiri uygulanmışsa, yüklenen fiili işlemediğinden dolayı hakkında beraat kararı veya kovuşturmaya yer olmadığına dair karar verilmiş olması koşuluyla, yukarıdaki fikralara göre verilecek ceza yarı oranında artırılır.

(5) Aleyhine tanıklıkta bulunulan kişinin göz altına alınması veya tutuklanması hâlinde; yüklenen fiili işlemediğinden dolayı hakkında beraat kararı veya kovuşturmaya yer olmadiğına dair karar verilmiş olması koşuluyla; yalan tanıklık yapan kişi, ayrıca kişiyi hürriyetinden yoksun kalma suçuna ilişkin hükümlere göre dolaylı fail olarak sorumlu tutulur.

(6) Aleyhine tanıklıkta bulunulan kimsenin ağırlaştırılmış müebbet hapis veya müebbet hapis cezasina mahkûmiyeti hâlinde, yirmi ylldan otuz ylla kadar hapis cezasına; (..) $)^{8}$ hükmolunur.

(7) Aleyhine tanıklikta bulunulan kimsenin mahkûm olduğu hapis cezasının infazına başlanmış ise, altıncı fikraya göre verilecek ceza yarısı kadar artırılır.

(8) Aleyhine tanıklıkta bulunulan kişi hakkında hapis cezası dışında adli veya idari bir yaptırım uygulanmışsa; yalan tanıklikta bulunan kişi, üç yıldan yedi yıla kadar hapis cezası ile cezalandırılır.”

Madde Gerekçesi ${ }^{9}$ ise,

"Madde metninde yalan tanıklık suçu tanımlanmıştır.

Birinci fikraya göre, hukuka aykırı bir fiil nedeniyle başlatılan bir soruşturma kapsaminda tanık dinlemeye yetkili kişi veya kurul önünde

8 Madde metninde yer alan "süreli hapis cezasina mahkumiyet halinde, mahkum olunan cezanın üçte ikisi kadar hapis cezasına" ibaresi, Anayasa Mahkemesi'nin 14.01.2015 tarihli ve E. 2014/116, K. 2015/4 sayılı kararı ile iptal edilmiştir. (RG:29 Nisan 2015/29341)

9 TBMM, Dönem: 22, Yasama Y1lı: 2, Sira Sayıs1:664, s.666 
gerçeğe aykırı olarak tanıklık yapılması, bu suçun temel şeklini oluşturmaktadır. Suçun temel şekli açısından tanık dinlemeye yetkili kişi veya kurulun yemin verdirmeye yetkisinin olmamast gerekir.

Ikinci fikraya göre ise, yalan tanıklık suçunun mahkeme huzurunda ya da yemin ettirerek tanık dinlemeye kanunen yetkili kişi veya kurul önünde işlenmesi, daha ağır ceza ile cezalandırılmayı gerektirmektedir. Suçun maddî unsuru yalan söylemek veya tanıklı̆̆ın konusunu oluşturan hususlar hakkındaki bilgiyi, bilerek, kısmen veya tamamen saklamaktır. Yalan söylemek deyimi, tabiî olarak gerçeği inkar etmeyi de kapsamaktadır. Tanık, tanıkliğının konusunu oluşturan hususlar hakkındaki bilgisini veya gördüğünü tam olarak açıklamakla yükümlüdür.

Üçüncü fikraya göre; kanuni tanımında üst sınırı üç yıldan fazla hapis cezasını gerektiren bir suçun soruşturma veya kovuşturması kapsamında yalan tanıklı yapılması, suçun temel şekline nazaran daha ăgır ceza ile cezalandırlmayl gerektirmektedir.

Maddenin dört ila sekizinci fikralarında yalan tanıklık sonucu meydana gelen neticelere göre fail hakkındaki cezanın ne surette tertip edileceği gösterilmektedir." şeklindedir.

Maddenin 1. fikrasında suçun temel şekli düzenlenmiş iken, devam eden fikralarda nitelikli halleri yer almıştır. TCK'nın 273. maddesinde şahsi cezasızlık veya cezayı azaltan nedenleri, 274. maddesinde de etkin pişmanlık hali düzenlenmiştir. Kanuni düzenleme böyle olunca bu makalede de konu sıralaması gözetilerek inceleme yapılacaktır.

Yalan tanıklık suçunun basit hali tehlike suçu iken, 2 ve devamı fikralarda düzenlenen nitelikli halleri (tutuklama, koruma tedbiri uygulanması, mahkumiyet hallerinin gerçekleşmesi durumları) zarar suçudur.

\section{A. Korunan Hukuki Değer}

Anayasa'nın 9. maddesine göre yarg1 yetkisi, Türk milleti adına bağımsız mahkemelerce kullanılır. Nasıl ki her kişinin Avrupa İnsan Hakları Sözleşmesinin 6. maddesinde düzenlenen adil yargılanma hakkı varsa Devletin de Anayasanın 36. maddesi uyarınca kişilere karşı adil yargılanma hakkını eksiksiz sağlamak görevi vardır ${ }^{10}$.

10 HAFIZOĞULLARI, Zeki/ÖZEN, Muharrem, Türk Ceza Hukuku Özel Hükümler Millete ve Devlete Karşı Suçlar, US-A Yayıncılık, Ankara 2016, s.156. 
Adil yargılanma hakkının ${ }^{11}$ korunması hükme esas alınacak delillerin hukuka uygun elde edilmiş ve gerçekleri içeriyor olmasına bağlıdır. $\mathrm{Bu}$ bağlamda tanık beyanı önemli bir delildir ve mahkeme huzurunda veya tanık dinlemeye yetkili kişi veya kurul önünde yeminli (CMK m. 54) veya yeminsiz (CMK m. 50) dinlenen tanık doğruları söylemekle yükümlüdür. Aksi halde adaletin tecellisi zarar görecek, maddi gerçek ortaya çıkmayacak ve toplumdaki adalete olan güven sarsılacaktır.

Öğretide suçla korunan hukuki değerin "adaletin doğru tecelli ettirilmesi" 12 , "kanıt vasitalarının korunması" 13 veya "adil yargılanma hakk1" ${ }^{14}$ olarak tespit eden görüşler var ise de bizim de savunduğumuz ve son dönem yargı kararlarında ${ }^{15}$ da yer alan görüşe göre, yargılama faaliyetinde önemli bir ispat aracı olan tanık beyanıyla maddi gerçeğin ortaya çıkarılması ve böylece adaletin tecellisine yalan karışması tehlikesinin önlenmesine ilişkin kamu yararıdır. Yani adalete duyulan güvendir.

\section{B. Suçun Unsurları}

\section{Maddi Unsurlar}

\section{a. Fail}

Kanuni düzenlemede "..tanıklık yapan kimse.." tabiri kullanıldığına göre, suçun faili hukuk düzeninin kendisine "tanık" sıfatı verdiği kişilerdir. Failin bu sıfatından dolayı kamu görevi yürüttüğü kabul edilmektedir ve suç faildeki sıfat nedeniyle özgü suçtur. Yani tanık sıfatı taşımayan bir kişinin kanunda belirtilen makamlar önünde gerçeğe uygun olmayan beyanda bulunması veya bir kısım konuları saklaması halinde bu suç oluşmayacaktır.

11 YAŞAR, Osman / GÖKCAN, Hasan Tahsin / ARTUÇ, Mustafa, Yorumlu-Uygulamalı Türk Ceza Kanunu, C. 6, 2. Bask1, Adalet Yayınevi, Ankara 2014, s. 8182. Yazarlara göre yalan tanıklık suçu ile korunan asıl hukuki değer kişilerin adil yargılanma hakkıdır. Yargılama sırasında mahkemenin kanaatini oluşturması bakımından önemli ispat araçlarından biri olan tanık beyanının gerçeğe aykırı oluşturulması suretiyle bireyin adil yargılanma hakkı ihlal edilmektedir.

12 ÖZBEK, Veli Özer/DOĞAN, Koray/BACAKSIZ, Pınar/TEPE, İlker, Türk Ceza Hukuku Genel Hükümler, Seçkin Yayıncılık, 11. Baskı, Ankara 2020, s. 1173.

13 SOYASLAN, Doğan, Ceza Hukuku Özel Hükümler, Yetkin Yayınevi, 11. Baskı, Ankara 2016, s.738.

14 YAŞAR, Osman /GÖKCAN, Hasan Tahsin /ARTUÇ, Mustafa, Yorumlu-Uygulamalı Türk Ceza Kanunu, s.7931.

15 Yargitay Ceza Genel Kurulu 03.12.2020 günlü, E. 2018/9-298 sayılı kararı. 
Tanık teknik bir terim olup, muhakemenin konusunu oluşturan olayla ilgili beş duyusuyla vakıf olduğu bilgiyi aktaran ve anılan olayın taraflarından olmayan kişidir ${ }^{16}$. Her ne kadar Kanunda (CMK m. 236) suçtan zarar gören ve mağdurun dinlenmesi sirasında tanıklara özgü kuralların uygulanacağını düzenlemiş ise de bu kişiler uyuşmazlık konusunun tarafı oldukları için yalan tanıklık suçunun faili olamazlar. Şüpheli olarak soruşturma ifadesinde yalan yanlış bilgiler veren kişi hakkında Kovuşturma Yapılmasına Yer Olmadığına Kararı verildikten sonra başkaları hakkında açılan davada bu beyanların yer alması dolayısıyla yalan tanıklık suçu oluşmaz. Çünkü bu suçun oluşması için yalan ya da eksik bilginin verildiği sırada kişinin "tanık" sıfatını taşıması zorunludur. Dolayısıyla hukuk davalarındaki dava taraflarının dinlenilmeleri sırasında söyledikleri yalan beyanlar nedeniyle yalan tanıklık suçu oluşmaz ve fakat yemin deliline dayanılmış ise ve yalan yere yemin ettiklerinin sübut bulması halinde TCK'nın 275. maddesinde düzenlenen "Yalan Yere Yemin" suçunun faili olabilirler.

Yargıtay süregelen kararlarında yalan tanıklık suçunun faili için soruşturma veya kovuşturma aşamasındaki olayın taraflarından olmaması şartını aramaktadır ${ }^{17}$. Yargıtay kararlarında netlikle adaletin tecellisi ile

16 ŞAHIN/GÖKTÜRK, C. 2, s. 33. Tanık tarafından edinilen bilginin her zaman doğrudan olması mümkün değildir. Bazen, dolaylı edinilmiş bilgi de söz konusu olabilir. Olayı bizzat görmüş olan kişi(ler)den olay hakkında bilgi sahibi olan birisi dolaylı tanık durumundadır. Olay hakkında doğrudan bilgi sahibi olan tanığa çeşitli nedenlerle ulaşılamaması, tanıklık yapmaması gibi durumlarda, ondan bilgi sahibi olan kişinin, duyduğunu söyleyen olarak dolaylı tanıklığı gündeme gelmektedir. Bu kişi, tanığın daha önce ifadesini almış olan kolluk görevlisi, Cumhuriyet savcısı veya hakim olabileceği gibi; gizli bilgi kaynağından bilgi alan bir görevli ya da bir olay hakkında dolaylı bilgi sahibi olan her hangi bir üçüncü kişi olabilir. Özellikle örgütlü suçlulukla mücadele çerçevesinde gizli soruşturmacının ya da örgüt içinde (güvenilir kişi) veya dışında (informant, bilgi veren) olup, soruşturma ve kovuşturma makamlarına bilgi aktaran özel şahsın anonim kalması nedeniyle bundan duyduğunu aktaran kişinin tanıklığı söz konusu olabilir. Dolaylı olarak bilgi edinmiş kişilerin tanıklığı, "ikinci derece tanıklık" veya "tanıklığın tanıklığı" olarak da adlandırılmaktadır. Gerçekten bu kişiler, bilgilerini olayın tanı̆̆ı olmuş bir başkasından edindikleri için, bir bakıma tanıklığın tanıklığını yapmaktadırlar. Ayrıca, bilgileri orijinal, ilk elden olmadığı için de tanıklıkları ikinci derecedir. Bkz. ŞAHİN/GÖKTÜRK, s. 35. Dolaylı tanık da bu suçun faili olabilir. Tanıklığının dolaylı olması, doğruyu söyleme yükümlülüğünü ortadan kaldırmaz. Doğruyu söyleme yükümlülüğü bakımından doğrudan tanık ile dolaylı tanık arasında bir farklılık gözetilerek, dolaylı tanığın gerçeğe aykırı beyanı da yaptırımsız bırakılamaz.

17 Yargitay 11. CD, 20.2.2014, E. 2014/11, K. 2014/2951 “TCK'nın 272. maddesinde düzenlenen yalan tanıklık suçunun oluşması için; ... hukuksal bir uyuşmazlığa konu bir olayla ilgili olarak bilgisini aktaran kişinin yasalar gereği "tanık" sıfatıyla dinlenilmesi gerekli olup, anılan suç, kendisinin katılmadığg olaylara ilişkin bildiklerini tanık dinlemeye 
tarafların haklarının korunmasının amaçlandığı belirtilmekte ve yalan tanıklık suçuyla yargılamanın gerçeğe aykırı bir yönlendirmenin önüne geçilmeye çalışıldığ 1 vurgulanmaktadır ${ }^{18}$. Yargıtay Ceza Genel Kurulunun 489-154 sayılı kararında da ayrıntılarıyla geçtiği üzere, tanığın gerçeğe aykırı her beyanı yalan tanıklık suçunu oluşturmayacaktır ${ }^{19}$. Bu nedenle tanığın doğru sandığı açıklamaların objektif olarak gerçek dişı olması bu suçun oluşması için yeterli değildir. Tanığın bilinçli olarak gerçekten ayrılması gerekmektedir. $\mathrm{Bu}$ itibarla tanık, algıladığ1 olayı tamamen algıladığı biçimde samimiyetle anlatması halinde yalan tanıklıktan bahsedilmemelidir. Yalan, gerçeğin kasten değiştirilmesi olup, yanılarak, ihmal ederek veya bilmeyerek söylenen sözlerde suçun unsurlarının oluşmadığı kabul edilmelidir.

Öğretide suçun kim tarafindan işlenebileceğine dair herkes tarafindan işlenebilen suçlar, özgü suçlar ve bizzat işlenebilen suçlar olmak üzere üçlü ayırım yapılmaktadır ${ }^{20}$. Yalan tanıklık suçunun özgü suç olup olmadığ hususu öğretide tartışmalıdır. Yalan tanıklık suçunda fail, "Hukuka aykırı bir fiil nedeniyle başlatılan bir soruşturma kapsamında tanık dinlemeye yetkili kişi veya kurul önünde gerçeğe aykırı olarak tanıklık yapan kimse" şeklinde tanımlanmıştır. Bu bağlamda yalan tanıklık suçunun faili, tanık sıfatı ile dinlenen kişi olup, beyanının tanık dinlemeye yetkili merci tarafından

yetkili merciler önünde açıklamaya zorunlu olan kimselerin yalan söylemesi veya gerçeği inkar etmesi yahut dinlendiği konudaki bilgilerini az veya çok söylememesi ile gerçekleşir."

18 Yargıtay CGK, 1.4.2014, E. 2013/4-498, K. 2014/154. "Yalan tanıklık suçuyla yargılamanın doğru olmayan beyanlarla gerçeğe aykırı bir şekilde yönlendirilmesinin önüne geçilerek adaletin tecellisi sağlanmak suretiyle yargılamanın taraflarının haklarının zarar görmesinin engellenmesi amaçlanmaktadır."

19 Yargitay CGK, 01.04.2014, E. 2013/4-498, K. 2014/154.

20 İNCE TUNÇER, Asuman, Yalan Tanıklık Suçu, Hacettepe Üniversitesi Sosyal Bilimler Enstitüsü Kamu Hukuku Anabilim Dalı Doktora Tezi, Ankara 2019, s.66. "Suçlar, fail bakımından suç tipinde aranan niteliğe göre herkes tarafından işlenebilen suçlar, özgü suçlar ve bizzat işlenebilen suçlar olmak üzere üçlü bir ayrıma tabi tutulmaktadır. Suça ilişkin kanuni tipte failin "kim", "kimse" gibi kelimelerle ifade edildiği, fail bakımından hiçbir ayrıştırıcı ibarenin kullanılmadığı suçlar, herkes tarafından işlenebilen suçlardır. Özgü suçlarda ise her kim, kimse ifadeleri yerine failin belli özellikleri belirtilir. Bu suçlar yalnızca kanuni tipte tanımlanan kişilerce işlenebilir. Özgü suçlar da kendi aralarında gerçek özgü suçlar ve gerçek olmayan özgü suçlar şeklinde ikiye ayrılmaktadır. Gerçek özgü suçlar, yalnızca özel faillik niteliğini taşıyanlar tarafından işlenebilen suçlardır. Gerçek olmayan özgü suçlarda ise suçun temel şekli herkes tarafından işlenebilmekle birlikte, nitelikli hali yalnızca özel faillik sıfatını taşıyan kişilerce işlenebilmektedir. Gerçek özgü suçların özel bir şeklini bizzat işlenebilen suçlar oluşturmaktadır. Bizzat işlenebilen suçlarda tipik fiilin doğrudan doğruya failin kendisi tarafından yapılması gerekir." 
alınması gerekir. Dolayısıyla tanık sıfatı uyuşmazlık konusu ortaya çıktıktan sonra edinildiğine göre bu sıfatı alabilecek herkes suçun faili olabileceğinden yalan tanıklık suçu gerçek özgü suçtur ve bizzat işlenebilen suçlardandır.

\section{b. Mağdur}

Ceza muhakemesi hukukunda ceza davasına katılma kurumu nedeniyle suçun mağdurunun tespiti önem taşımaktadır. CMK'nın m. 237/1 uyarınca, mağdur ve suçtan zarar gören gerçek ve tüzel kişiler şikayetçi olduklarını belirterek kamu davasına katılabilirler. Ceza Muhakemesi Kanunumuzda mağdur ve suçtan zarar gören farklı kavramlardır. Suçtan zarar gören kavramı, mağdur kavramını da içeren daha geniş bir kavramdır. İşlenen suç ile hakları doğrudan veya dolaylı olarak zarara uğrayan herkes "suçtan zarar gören" sıfatını alırken, işlenen suç tanımında korunan hukuki menfaatin sahibi olan kimse "mağdur" sıfatını almaktadır.

"Mağdur" kavramı, dar anlamda mağdur ve geniş anlamda mağdur olmak üzere iki aşamada ele alınmaktadır. Bu bağlamda suç bir kişiye ait hukuki menfaati doğrudan doğruya etkilemiş ise o kimse suçun dar anlamda mağduru iken, kişi doğrudan doğruya değil de üyesi bulunduğu topluma ait genel bir menfaatin zedelenmesi nedeniyle etkilenmiş ise bu halde de geniş anlamda mağdur sıfatını almaktadır. Suçla korunan hukuki menfaat, belli bir kimseye ait olabileceği gibi toplumu oluşturan herkese ait de olabilir. $\mathrm{Bu}$ sebeple devlete ve millete karşı işlenen suçlar ile topluma karşı işlenen suçlarda mağdur toplumu oluşturan herkestir. Bazı hallerde ise suçtan toplumu oluşturan herkes geniş anlamda mağdur olurken, belli kişi/kişiler de dar anlamda mağduru olabilir.

Yalan tanıklık suçunun korunan hukuki menfaatinin sahibine göre mağdurunun tespiti öğreti de tartışmalıdır. Adliyeye karşı işlenen suçlarda ve "yalan tanıklık" suçunda korunan hukuki menfaatin sahibi yargı erki olan yarg1 makamları adına Devlet yani Adalet Bakanı olduğunu savunan görüşler ${ }^{21}$ olduğu gibi, suçla birden fazla hukuki menfaatin korunduğu görüşünde olanlara göre mağdur hem toplumu oluşturun herkes hem de özelde aleyhine yalan beyanda bulunulan ve zarar gören kişi de suçun mağduru sıfatını alabilmelidir ${ }^{22}$. Bir başka görüşe göre de suçun mağduru adaletin doğru tesisi tüm toplumu yakından ilgilendirdiğine göre toplumu oluşturan herkestir ${ }^{23}$.

21 HAFIZOĞULLARI/ÖZEN, Özel Hükümler, s.157.

22 ARTUK, Mehmet Emin/GÖKCEN, Ahmet/YENIDÜNYA, Caner, Ceza Hukuku Genel Hükümler, Adalet Yayınevi, s.314.

23 ÖZBEK, Veli Özer/DOĞAN, Koray/BACAKSIZ, Pınar, Türk Ceza Hukuku Özel 
Kanaatimizce de mağdur sıfatı gerçek kişiler için kullanılmalıdır. Yalan tanıklık suçu ile adil yargılanma hakkı ihlal edilen kişi/kişiler suçun mağduru olduğu gibi korunan hukuki değerin sahibi olarak belli bir kişi tespit edilemese dahi adaletin tecellisinde tüm toplumun menfaati bulunduğuna göre toplumu oluşturan herkes suçun mağduru olmaktadır.

\section{c. Suçun Konusu}

Her suçun konusu olduğu gibi yalan tanıklık suçunun da konusu vardır. Öğretide büyük oranda kabul edildiği şekliyle "suçun hukuki konusu, Devletin yargılama faaliyetinde, tanıklı adı altında, hala bir ispat aracı olarak vazgeçilmez olan tanık bilgisinin doğruyu bütün ve eksiksiz ifade etmesine, yargı kararlarına yalan karışması tehlikesinin önlenmesine ilişkin kamusal yarar olmaktadir ${ }^{24}$.

İster yeminli ister yeminsiz dinlensin kendisine gerçeği söylemesinin önemi anlatılan ve aksi halin suç oluşturacağının ihtarı yapılan tanık, kendisine sorulan maddi olayla ilgili bildiklerini eksiksiz/tam ve doğru olarak anlatmakla yükümlüdür. Dolayısıyla, yalan tanıklıkta bulunan fail, geçmişte yaşanmış ve yargılamaya konu edilen maddi gerçekliği kasten değiştirerek anlatmakta veya vermesi gereken bilgiyi vermeyerek/saklayarak beyanda bulunmaktadır. Bu bağlamda yalan tanıklık suçunun konusu, ceza muhakemesinin sebebi olan olay, maddi gerçeklik yani aydınlatılmaya çalışılan vakıadır.

\section{d. Fiil}

Kanuni düzenlemesindekine uygun bir fiilin bulunması, suçun oluşması için şarttır. Suçun varlığı tipik bir fiilin varlığına bağlıdır. Fiil insan iradesinin ürünü olup, bir amacı gerçekleştirmek için dış dünyaya yansıyan icrai veya ihmali davranışların tümüdür.

Suçun tipikliğindeki hareketin meydana getirdiği etkiye göre öğretide ve uygulamada suç tipleri belirtilmiştir. Tipik hareketin yapılmasıyla bir zarar meydana gelmekte suç konusu değer kaybına uğramakta ise suç zarar suçu adını almakta; herhangi bir zararın doğması şart olmaksızın suç konusunun zarara uğrama tehlikesi doğması halinde ise tehlike suçu meydana gelmektedir. Tehlike suçları da "somut tehlike suçu" ve "soyut

Hükümler, Seçkin Yayıncılık, Ankara 2020, s.1147.

24 HAFIZOĞULLARI/ÖZEN, Özel Hükümler, s.157; ARTUK, Mehmet Emin/GÖKCEN, Ahmet/YENIDÜNYA, Caner, Ceza Hukuku Özel Hükümler, Adalet Yayınevi, Ankara 2014, s.1063. 
tehlike suçu" olmak üzere ikiye ayrılmaktadır. Somut tehlike suçlarında, hareketin cezalandırılabilmesi için suçun konusu üzerinde somut bir tehlikenin yaratılmış olması gerekir. Soyut tehlike suçlarında ise suçun kanuni tanımında yer verilen hareketin yapılması suçun oluşması bakımından yeterli görülmüştür. Soyut tehlike suçlarında hareketin yapılması ile suç oluşur, suçun konusunun tehlikeye düşüp düşmediğinin araştırılmasına gerek yoktur ${ }^{25}$.

Bu açıklamalar ışığında TCK'nın 272. maddesinin düzenlenen yalan tanıklık suçunun basit halinin oluşması için somut bir zararın doğması şart koşulmadığı gibi, somut bir zararın tehlikesinin de gerçekleşmesi şart değildir. Yalan beyan ile maddi gerçeğin ortaya çıkarılmasının yani adaletin tecellisinin tehlikeye girdiği kabul edilmektedir. Tehlikenin varlığ değildir. Dolayısıyla yalan tanıklık suçu soyut tehlike suçudur.

Buna karşılık anılan Kanun maddesinin 4 ila 8. fikralarında düzenlenen suçun neticesi sebebiyle ağırlaşmış halleri ise aleyhinde yalan tanıklıkta bulunulan kişi bakımından zararlı bir neticenin meydana gelmesi ile oluşmaktadır. Dolayısıyla yalan tanıklığın nitelikli halleri zarar suçu niteliğindedir.

Suçun oluşması kanuni tipe uygun bir fiilin bulunmasına bağlıdır ${ }^{26}$. Fiziki dünyada bir seri fiil, hukuki anlamda tek bir fiili oluşturabilecekken, fiziki bir tek fiil hukuki anlamda birden fazla fiil olarak isimlendirilebilir. Ancak "kanunsuz suç olmaz" ilkesi gereğince bir fiilin suç olması için işlenmeden önce Kanunda tanımının ve yaptırımının düzenlenmesi gereklidir.

Yalan tanıklık suçunun fiil unsuru TCK'nın 272. maddenin ilk fikrasında, "hukuka aykır bir fiil nedeniyle başlatılan bir soruşturma kapsamında tanık dinlemeye yetkili kişi veya kurul önünde gerçeğe aykırı olarak tanıklık yapmak" şeklinde ifade edilmiştir.

Tipikliğin fiil açıklaması üç basamaktan oluşmaktadır. İlk olarak hukuka aykırı bir fiil nedeniyle başlatılan soruşturma olmalı, ikinci olarak, Türk hukukunda, hukuka aykırı bir fiil nedeniyle başlatılan bir soruşturma kapsamında tanık dinlemeye yetkili kişi ve kurullar huzurunda olunmalı ve son olarak da verilen beyanın gerçeğe aykırı olması gerekmektedir.

25 İNCE TUNÇER, Yalan Tanıklık Suçu, s.81.

26 KOCA, Mahmut/ÜZÜLMEZ, İlhan, Türk Ceza Hukuku Özel Hükümler, Adalet Yayınevi, 7. Bask1, Ankara 2020, s. 88, 97. 
Kanuni düzenlemedeki soruşturma kavramından yalnızca Ceza muhakemesinin bir aşaması olan soruşturma evresi anlaşılmamalıdır. Çünkü hukuka aykırı fiil kavramı suç kavramından daha geniş anlamdadır. Fiil ile hukuki nizam arasında bir çatışmanın varlığı hukuka aykırılık için kafidir. Zira hukuka aykırı fiiller haksız fiil olsa da illa ki suç olması şart değildir. Suç olmayan haksız fiillerin varlığıyla bir tetkik yürütülüyorsa, ceza hukuku anlamında soruşturma ve kovuşturma aşamalarında, özel hukuk uyuşmazlıklarının çözümü süreçlerinde ve idari yargı soruşturmaları ve disiplin soruşturmaları sırasında tanık dinlemeye yetkili makamlar huzurunda olunması halinde yalan tanıklık mümkündür.

Ceza hukuku soruşturma evresinde tanık dinlemeye yetkili makamlar Cumhuriyet Savcısı ve Sulh Ceza hakimliğidir. Kolluğun tanık dinleme yetkisi olmadığından yaptığ konu olabilir. Dolayısıyla kolluğun aldığı tanık beyanındaki gerçeğe aykırı ifadeler yalan tanıklık suçunu oluşturmayacak ve fakat kapsamına göre faillerin veya suç delillerinin gizlenmesi, değiştirilmesi veya suç uydurma ya da iftira suçlarına vücut verebileceği unutulmamalıdır.

Yargıtay'ın süre gelen uygulamalarında da bu hususa istikrarlı bir şekilde değinilmektedir ${ }^{27}$. Yargitay son yıllarda da kararlarında kolluk görevlilerinin tanık dinleyemeyeceğini ve kollukta müşteki olarak ifade verilmesi halinde de yalan tanıklık suçunun oluşmayacağını vurgulamaktadır ${ }^{28}$. Benzer şekilde kollukta verilen gerçeğe aykırı beyanların yalan tanıklık suçunu oluşturmayacağ 1 karar altına alınmıştır ${ }^{29}$. Bununla birlikte Yargıtay istikrarlı kararlarında cezalandırılma için mutlaka tanık sıfatılla ifade vermeyi aramaktadır ${ }^{30}$.

Yalan tanıklık suçu serbest hareketli bir suçtur. Yetkili makamlar önünde beyanda bulunan kişi bilerek isteyerek-kasten gerçeği değiştirerek

27 Yargitay 4. CD, 24.6.2009, E. 2009/16212, K. 2009/12656. "Adli görevleri nedeniyle kolluk görevlilerinin olayla ilgili görgüsü olan kişileri "ifade sahibi" slfatıyla dinlemeleri, onlara "tanık" sıfatını vermemekte ve yasadaki tanıklı̆̆a ilişkin hükümlerin uygulanmasını gerektirmemektedir. Dolayısıyla doktrinde de belirtildiği üzere ... kolluğun "tanık dinleme" yetkisi bulunmamaktadır."

28 Yargitay 16. CD, 28.12.2016, E. 2016/3660, K. 2016/7614. "Somut olayımızda sanık N.Ö. 'nün kolluk görevlilerince tanık olarak değil müssteki olarak ilk ifadesini vermesi karşısında, üzerine atılı suçun yasal unsurları oluşmadığı gözetilmeden mahkumiyet kararı verilmesi bozmayı gerektirmiştir."

29 Yargitay 16. CD, 24.11.2016, E. 2016/4819, K. 2016/6077.

30 Yargitay 16. CD, 28.12.2016, E. 2016/3660, K. 2016/7614. “...sanığın yalan tanıklı suçundan cezalandırılabilmesi için daha önce tanık sıfatı ile beyanda bulunması ve bu beyanların doğru olmadiğının ortaya çıkması gerekmektedir." 
ifade verebileceği gibi kısmen veya tamamen gerçekleri saklayarak da beyanda bulunması halinde suç işlenmiş olacaktır.

Kanuni belirlilik ilkesi 1şı̆̆ında sağır ve dilsiz olan tanıkların işaret diliyle verdikleri ifadeleri ile yazarak verdikleri ifadeleriyle de suça konu olabilirler. Maddi gerçeğin ortaya çıkmasını önlemeye yönelik tanığın suskunluğunda da yalan tanıklık suçu oluşabileceği gibi doğrudan soruşturma veya kovuşturma konusunu oluşturmayan ve tahkikatın seyrini değiştirmeyen sair konulardaki gerçeğe aykırı beyan yalan tanıklık suçunu oluşturmayabilecektir. Tanığın suskunluğunun istisnası tanıklıktan çekinme hakkını haiz tanıklardır. Bu kişilerin susma haklarını kullanarak suskun kalmaları suça vücut vermez. Tanıklıktan çekinme hakkı bulunan kişiye bu hakkının hatırlatılmaması halinde gerçekle örtüşmeyen beyanlarının yalan tanıklık suçunu oluşturmayacağına dair Yargıtay'ın süregelen kararları mevcuttur. Dolayısıyla her olayın özelinde inceleme ve değerlendirme yapilması şarttır.

\section{Manevi Unsur}

Fail ile fiil arasındaki manevi bağ suçun manevi unsurunu oluşturur. Yalan tanıklık suçu kasten işlenebilen bir suçtur. Kasten işlenirken failin taşıdığ 1 saik önemli değildir.

Kast unsurunun oluşması açısından üç önemli tespitin yapılması gereklidir. Birincisi, kişinin beyanının "tanık" sıfatıyla alındığını bilmesi gerekir. İkincisi, beyanını dinleyen makamın tanık dinleme yetkisinin bulunması ve üçüncü ve son olarak da tanık sifatıyla ifade verenin gerçeğe aykırı biçimde açıklamalarda bulunduğunu veya gerçeği gizlediğini bilmesi şarttır. Tanığın gizlediği veya değiştirdiği gerçeklerin ispatla ilgili olduğunu da bilmesi aranmalıdır ${ }^{31}$. Kişi tanık olduğunu bilmiyorsa ya da beyan verdiği makamın tanık dinlemeye yetkili olduğunu bilmiyor ise TCK'nın 30 . maddesi kapsamında hata var ise suçun kasıt unsuru oluşmayacağından ceza verilmesi mümkün değildir.

Tanık dinlemeye yetkili merciin yetkisinin dinleme olması kafidir, yemin verdirme yetkisinin bulunması şartı aranmaz. Tanığın olayın üzerinden geçen zaman veya şahsi nedenleri ile unutması veya dalgınlığ nedeniyle gerçeğe aykırı beyanda bulunması halinde de suç oluşmayacaktır. Ancak birden fazla kişinin yargılandığı bir dosyada bir sanık ile ilgili beyan verecekken hata ile farklı veya fazla kişiler hakkında beyanda bulunması

31 HAFIZOĞULLARI/ÖZEN, Özel Hükümler, s.162. 
halinde ise hatasından yararlanması düşünülemez, bu halde de suç oluşacaktır.

Suçun taksirle işlenmesi mümkün olmadığı gibi kanaatimizce olası kast ile de işlenmesi söz konusu değildir.

\section{Hukuka Aykırılık Unsuru}

Hukuka aykırılık unsuru suçun tipik fiilinin hukuki düzenle çatışması halidir. Yani fiilde hukuka uygunluk halleri var ise eylem suç olmaktan çıkacaktır. Hukuka aykırılık hali sadece ceza hukukuna aykırılık olarak alınmamalıdır. Fiilin tüm hukuk düzenine aykırı olması anlamındadır. Zira hukuka uygunluk halleri de sadece ceza hukukundan değil, özel hukuktan, idare hukukundan, kamu hukukundan ve hatta örf ve adetten kaynaklanabilir.

Yalan tanıklık suçu ile korunmak istenen değer, maddi gerçeğin ortaya çıkarılmasına ilişkin toplumun menfaati ve kişilerin adil yargılanma hakkıdır. Adliyeye karşı işlenen suçlardan olması nedeniyle hakkında yalan beyanda bulunulan kişinin rızası fiilin hukuka aykırılığına etki etmeyecek ve eylemi suç olmaktan çıkarmayacaktır.

\section{Nitelikli Unsurlar}

Öğretide ağırlıklı olarak bir ayrım yapılmaksızın TCK'nın 272. maddesinin 2 ilâ 8. fikralarında yer alan düzenlemeler cezayı ağırlaştıran nedenler ya da nitelikli haller başlığı altında ele alınmaktadır. Ancak ayırım yapılması gerektiği görüşünde olanlara göre TCK'nın 272. maddenin 4 ilâ 8 . fikralarında yer alan düzenlemeler, neticesi sebebiyle ağırlaşmış halleri iken 2 ile 3. fikraları ile yalan tanıklık suçunun nitelikli halleri olarak öngörülmüştür ${ }^{32}$.

Suçun nitelikli halleri, suçun tipiklik unsurlarına ek olarak cezanın artırılmasını ya da azaltılması gerektiren bir neden bulunmaktadır. Suçu nitelikli hale getiren unsurun dahi suçun unsurlarına dahil olması nedeniyle failin kastının da bu nitelikli unsuru içermesi gerekmektedir. Neticesi sebebiyle ağırlaşan hallerde ise nitelikli hallerden farklı olarak suçu oluşturan fiilin neticesinin öngörülenden ağır olması sonuçlanması durumudur. Yani neticenin ağırlaşmasıyla veya ilave bir neticenin daha meydana gelmesiyle suça verilecek cezanın temel şekline göre verilen cezadan daha ağır olması halidir. Suçun nitelikli halinde kasıt unsuru önem taşır yani failin kastı nitelikli halleri de içermelidir. Neticesi sebebiyle ağırlaşan hallerde ise failin en azından taksirle hareket etmesi gerekmektedir.

32 İNCE TUNÇER, Yalan Tanıklık Suçu, s.85. 
Yalan tanıklık suçunun düzenlendiği TCK'nın 272. maddesinin 2. ve 3. fikraları suçun nitelikli halleridir. Anılan maddenin ikinci fıkrasındaki düzenleme gerçeğe aykırı tanıklık olgusunun mahkeme huzurunda yahut yemin ettirerek tanık dinlemeye yetkili kimse veya kurul önünde gerçekleşmesi ilk nitelikli halidir. CMK uyarınca Cumhuriyet Savcısı, Sulh Ceza Hakimi, 4483 sayılı Kanun uyarınca ön inceleme yapan kimse, 657 sayılı Kanun uyarınca Yüksek Disiplin Kurulları ve Avukatlık Kanunu uyarınca disiplin soruşturmas1 yapan kimselerin yemin ettirerek tanık dinleme yetkileri bulunmaktadır. Mahkemeler kapsamına da hukuk, ceza ve idare mahkemeleri ve yüksek mahkemeler dahildir.

Maddenin üçüncü fikrasındaki düzenlemeye göre, suçun fiil unsurunun, üst sınır olarak üç yıldan fazla hapis cezası ön görülen suçların soruşturma veya kovuşturması çerçevesinde işlenmesi de bir diğer nitelikli haldir. Nazara alınacak olan maddesindeki soyut düzenlemenin üst sınırıdır. Hapis ve adli para cezasının birlikte düzenlenmesi halinde de hapis cezası esas alınmalıdır.

Suçun neticesi sebebiyle ağırlaşmış halleri maddenin 4. ila 8 . fikralarında düzenlenmiştir. Buna göre aleyhe gerçeğe aykırı tanıklıkta bulunulan kişi hakkında gözaltına alma ve tutuklama dışında bir koruma tedbiri uygulanmış olması; hapis cezası dışında adli veya idari yaptırım uygulanması ile söz konusu kişinin hapis cezasına mahkûm olması ve mahkum olduğu hapis cezasının infazına başlanması olarak sıralamak mümkündür. Gözaltına alma ve tutuklama dişındaki koruma tedbirleri, yakalama (CMK m. 90), adli kontrol (CMK m.109), zorla getirme (CMK m. 146), arama (CMK m. 116), elkoyma (CMK m.123), teknik araçlarla izleme (CMK m.139) sayılabilir.

Maddenin beşinci fikrasındaki aleyhine tanıklık yapılanın mahkumiyetine karar verilmesi halinde de verilen mahkumiyet kararının kesinleşmesi aranmaktadır.

TCK'nın 273. maddesinde de şahsi cezasızlık veya cezanın azaltılmasını gerektiren sebepler düzenlenmiştir.

a) Özel hukuka ilişkin uyuşmazlık hallerinde yapılan yalan tanıklık hali hariç olmak üzere, kişinin üstsoy, altsoy, eş veya kardeşinin soruşturma veya kovuşturmaya uğramasına neden olabilecek bir hususla ilgili yalan beyanda bulunması halinde;

b) tanıklıktan çekinme hakkı olmasına rağmen bu hakkı kendisine hatırlatılmadan gerçeğe aykırı tanıklık yapması halinde mahkemece gerekçeleri gösterilmek suretiyle cezalarında indirim yapılabileceği gibi ceza vermekten de büsbütün vazgeçilebilir. 


\section{Kusurluluk}

Yalan tanıklık suçu kastla işlenen bir suçtur. Kast ise doğrudan kasttır. $\mathrm{Bu}$ suç olası kastla işlenemez. Ayrıca Kanun, tanığın tanıklık yaptığı sırada tedbirsiz ve dikkatsiz davranmasını da cezalandırmamaktadır. Yalan tanıklık yapan fail, tanık dinlemeye yetkili kişi veya kurul önünde bilerek ve isteyerek gerçekleri değiştirmekte veya bildiklerini tam söylememektedir. Dolayısıyla unutma, algılamada eksiklik ya da samimiyetinden kuşku duyulmayacak şekilde yanılgıya düşme hallerinde suçun kasıt unsurunun oluşmadığı sonucuna varılmalıdır.

Öte yandan kusur, kişinin hukuka uygun davranma imkânı olmasına rağmen haksızlık işlemeyi tercih etmesi nedeniyle fail hakkında yürütülen kınama yargısı olarak da tarif edilmektedir ${ }^{33}$. Ceza Hukukunda kişi hakkında bu kınama yargısının yürütülebilmesi için kişinin kusur yeteneğine sahip olması aranmaktadır. İcra edilen fiilin hukuki anlam ve sonuçlarını algılama ve bu doğrultuda davranışlarını yönlendirme yeteneğinin varlığı kusur yeteneğidir $^{34}$. Kişinin davranışlarından sorumlu tutulabilmesi onun irade yeteneğidir.

Tanıklık yapanın iyi niyetinden şüpheye düşülmeyecek şekildeki insani sebeplere dayalı yanılg1 hallerinin varlığ halinde kasit unsurunun oluşmadığ 1 kabul edilmelidir. Bununla birlikte kişinin TCK'nın 25/2. maddesindeki zaruret halinde olması veya TCK'nın 28. maddesinde düzenlenen cebir şiddet ve korkutma altında olması hallerinde de olayın özelliğine göre değerlendirme yapılmalıdır. $\mathrm{Bu}$ konuda doktrindeki bir başka görüş, söz konusu durumları mazeret nedenleri başlığında incelemektedir: "Bu nedenler var olduğunda kusur etkilenmekte, haksızlık ve kusurunun içeriği azalmakta ancak bütünüyle ortadan kalkmamaktadır. Çünkü mazeret nedeni oluşturan hallerde fail hem kusur yeteneğine hem de haksızlık bilincine sahiptir. Bundan dolayıdır ki, mazeret sebepleri haksızlı̆̆ ve kusuru azaltan neden olarak görülmektedir. Ancak bu hallerde cezaya layı olma sinırına varılmadiğı için, kanun koyucu cezasizlık öngörmektedir." 35

33 KOCA/ÜZÜLMEZ, Özel Hükümler, s. 290. "Bir başka bakış açısında göre kusur yeteneği ve haksızlı bilinci, kusurun kurucu unsurları olup kusur yeteneğinin bulunmaması veya kaçınılmaz yasak hatası kusuru kaldıran nedenlerdir."

34 KOCA/ÜZÜLMEZ, Özel Hükümler, s. 291.

35 HAFIZOĞULLARI, Zeki, "Kusurluluğu Kaldıran Bir Neden Olarak Ceza Hukukunda İstenemezlik İlkesi”, Ankara Üniversitesi Hukuk Fakültesi Dergisi, Y11: 2008, Cilt: 57, Say1: 3, s. 338-360. 


\section{Suçun Özel Görünüş Şekilleri}

\section{Teșebbüs}

TCK'nın 35. maddesinde düzenlenmiş olan madde hükmüne göre suça teşebbüsün tanımı "Kişi, işlemeyi kastettiği bir suçu elverişli hareketlerle doğrudan doğruya icraya başlayıp da elinde olmayan nedenlerle tamamlayamaz ise teşebbüsten dolayı sorumlu tutulur." şeklindedir.

Öğretide yalan tanıklık suçuna teoride teşebbüsün mümkün olduğunu belirten görüşler ${ }^{36}$ bulunsa bile yalan tanıklık suçu yetkili kişi veya kurul önünde tanık sıfatı ile yalan beyanda bulunmakla tamamlanır. Sirf hareket suçu niteliğinde olduğundan gerçeğe aykırı beyanın yapılmasıyla suç tamam olacağından bu suça teşebbüsün mümkün olmadığı kanaatindeyiz. Tanığın beyanının yarım kalması halinde veya beyan sırasında tanığın gerçeğe dönerek bilgisini doğru vermesi hallerinde eylem henüz sonuçlanmamış olacağından teşebbüs değerlendirmesi yapılamaz. Zira insanların çekingenlik ve stres altında hatırlayamamak veya yanlış ifade etmek gibi durumlarla karşılaşması her zaman mümkündür. $\mathrm{Bu}$ hallerin insan psikolojisiyle doğrudan etkili olması da gözetilerek ifadenin tümü değerlendirilerek yalan tanıklık kastının varlığına hükmetmek gerekeceğinden teşebbüs mümkün değildir. Kişinin beyanı alan merciin TCK'nın 272. maddesinde belirtilen yetkileri haiz bir mercii olduğu kanısında dahi suç oluşmayacağından, bu haldeki yanılma da eylemi teşebbüs niteliğine sokmayacaktır.

\section{2. İștirak}

İștirak, bir kişi tarafından işlenmesi mümkün olan bir suçun birden fazla kişi tarafından ve birlikte suç işleme iradesi ile gerçekleştirilmesi halidir. TCK'nın 37 ila 41. maddeleri arasında düzenlenmiştir. Buna göre iştirak türleri faillik, azmettirme ve yardım etme şeklinde sıralanabilir. Türk ceza Kanunu suç ortaklarının cezai sorumluluğunun belirlenmesinde ikilik sistemini kabul etmiştir. İkilik sisteminde suç ortakların suça katılım durumuna göre faillik ve şeriklik olarak ikili bir ayrıma gidilmektedir. Buna göre failler ve şeriklerin cezai sorumluluğu ayrı ayrı belirlenmiştir.

Yalan tanıklık suçu kasten işlenen suçlardan olması nedeniyle iştirak mümkündür. Ancak özgü suçlardan olması nedeniyle iştirakin her halinin mümkün olduğunu savunan görüşler ${ }^{37}$ olduğu gibi sadece bazı hallerin vücut

36 FEYZİOĞLU, Tanıklık, s. 245; İÇEL, Kayıhan, Ceza Hukuku Genel Hükümler, Beta Yayıncılık, Ankara 2018, s. 210.

37 ÜNVER, Yener, Adliyeye Karşı Suçlar, Seçkin Yayıncılık, 3. Baskı, Ankara 2013, s. 222. 
bulacağı fikrini savunan, azmettiren veya yardım eden sıfatlarının kazanılmasına imkan tanıyacağını kabul eden görüşler ${ }^{38}$ de vardır.

TCK'nın 37. maddesinin 2. fikrasında dolaylı faillik düzenlenmiştir. Buna göre; "suçun işlenmesinde bir başkasını araç olarak kullanan kişi de fail olarak sorumlu tutulur. Kusur yeteneği olmayanları suçun işlenmesinde araç olarak kullanan kişinin cezası, üçte birden yarısına kadar artırılır". Dolaylı faillikte arka plandaki kişi, bir başka şahsın hareketini suçun işlenmesinde araç olarak kullanmaktadır. $\mathrm{Bu}$ kişi suç oluşturan fiili gerçekleştiren şahsın üzerinde hakimiyet kurmaktadır. Arkadaki şahsın dolaylı fail olarak sorumlu tutulmasının nedeni de bu hakimiyettir ${ }^{39}$. Yalan tanıklık suçunda dolaylı faillik kurumunun vücut bulup bulmayacağı öğretide tartışmalıdır. Ağırlıklı savunulan görüşe göre özgü suç ve bizzat işlenebilir suç olması nedeniyle suça azmettirme ve suça yardım şeklindeki iştirakler mümkündür.

TCK'nın 40. maddesinin 2. fikrasında özgü suçlarda iştirake ilişkin bir hüküm vaz edilmiştir. Yasal düzenlemeye göre; "Özgü suçlarda, ancak özel faillik niteliğini taşıyan kişi fail olabilir. Bu suçların işlenişine iştirak eden diğer kişiler ise azmettiren veya yardım eden olarak sorumlu tutulur". Kanunun özgü suçlara ilişkin bu açık düzenlemesi karşısında bize göre de yalan tanıklık suçuna azmettirme ve yardım etme şekillerinde iştirak olunabilir.

Yargıtay da süregelen istikrarlı kararlarında özgü suçlara özel faillik sıfatını taşımayan kimselerin ancak azmettiren ve yardım eden olarak katılabileceği yönünde karar vermektedir ${ }^{40}$. Benzer şekilde özgü suç olan

38 GÖKTÜRK, s. 400; ÖZBEK/DOĞAN/BACAKSIZ, Özel Hükümler, s. 1159; TEZCAN, Durmuş/ERDEM, Mustafa Ruhan/ÖNOK, Murat, Ceza Özel Hukuku, Seçkin Yayınevi, Ankara 2020, s. 1244. Bir görüşe göre, özgü bir suç olmadığından, suç ortaklığına ilişkin her hüküm yalan tanıklık suçu açısından uygulanma alanı bulabilir. Ancak belirtmek gerekir ki, yapılan bu değerlendirme ortaklık çeşitleri bakımından bir ayrıma gitmemiş, suçun bizzat işlenebilen bir suç olması nedeniyle ortaya çıkabilecek farklılıklar ele alınmamıştır. Genel olarak suçun iştirak bakımından bir özellik göstermediği ifade edilmiştir.

39 ÖZGENÇ, İzzet, Suça İştirak, İBB Hukuk Müşavirliği, İstanbul 1996, s. 197, 202. “....asıl failin araç konumuna indirgendiği ve fiil hâkimiyetinin arkada bulunan kişide olduğu durumlarda dolaylı faillik gündeme gelecektir." Bkz. TÖNGÜR, Ali Rıza, "Yargitay Kararları Doğrultusunda Isstirak Türü Olarak Dolaylı Faillik ve Azmettirme", Ceza Hukuku Dergisi, S. 28, Y. 2015, ss.223-259, s. 257.

40 Yargitay 11. Ceza Dairesi 21.11.2018, E. 2018/5164, K. 2018/9367 sayılı kararında "Görevi gereği düzenlemeye yetkili olduğu resmî belgeyi sahte olarak düzenleme" suçunun "özgü suç" olması karşısında; sanığın, diğer sanığa isnat olunan suça ne şekilde iştirak ettiği belirlenip tartışılmadan, sanığın 5237 sayıl TCK'nın md. 204/2 gereğince cezalandırılması bozmayı gerektirmiştir." demiştir. 
zimmet suçunda kamu görevlisi olmayan faillerin azmettiren veya yardım eden sıfatını alabileceği şeklinde kararlar vermiştir ${ }^{41}$. Özgü suçlarda dolaylı failliğin mümkün olmadığına dair pek çok emsal karar mevcuttur ${ }^{42}$.

Yalan tanıklık suçunda gerçeğe aykırı beyanları tanık sıfatını taşıyacak kişiye söyleten yalan iradesi yokken irade oluşturan azmettiren olarak sorumlu tutulacaktır. Bu suça yardım etme eylemleri de çeşitli şekillerde ortaya çıkabilir. Yalan tanıklık yapma niyeti bulunan bir kimsenin teşvik edilmesi, yalan tanıklık yapma kararında olan failin bu kararının kuvvetlendirilmesi, yalan tanıklıktan sonra yardımda bulunulacağının vaat edilmesi, yalan tanıklığın ne şekilde yapılacağı konusunda yol gösterilmesi ve suçun işlenmesinden önce yardımda bulunarak icrasının kolaylaştırılması hallerinde, yardım etmeden sorumluluk doğacaktır ${ }^{43}$.

\section{3. İçtima}

Türk Ceza hukukunda kural olarak kaç tane fiil varsa o kadar suç ve kaç tane suç varsa o kadar ceza vardır. Buna göre suçların içtiması kapsamına giren istisnalar dışında, işlenen her suçtan dolayı fail hakkında ayrı ayrı cezaya hükmedilir. Bir başka deyişle gerçek içtima kuralının istisnasını suçların içtimasına ilişkin düzenlemeler oluşturmaktadır. TCK'da suçların içtiması başlığı altında; bileşik suç, zincirleme suç ve fikri içtima hükümlerine yer verilmiştir. Bileşik suçun esasen görünüşte içtima hali olduğu kabul edilmektedir ${ }^{44}$. Aynı nevi'den fikri içtima zincirleme suç başlığı altında TCK'nın 43. maddesinin 2. fikrasında düzenlenmiştir. Farklı nevi'den fikri içtima ise TCK'nın 44. maddesinde düzenlenmiştir. Her iki

41 Yargıtay 5. CD, 16.2.2019, E. 2008/9242 K. 2009/1799 sayllı kararında "Zimmet suçu özgü suçlardan olup, kamu görevlisi olmayan sanığın TCK'nın 40/2. maddesine göre, azmettiren veya yardım eden olarak sorumlu tutulacağının nazara alınmaması yasaya aykırıdır." demiştir.

42 "Dava ihaleye fesat karıştırma suçuna ilişkindir. 5237 Sayılı TCK'nın 40/2. maddesine göre özgü suç niteliğinde olan, bu sebeple dolaylı failliğe elverişli bulunmayan ve TCK'nın 235/2-a maddesi uyarınca ihale sürecinde görevli kişiler tarafından işlenebilen ihaleye fesat karıştırma suçunun ihaleye teklif veren sanıklar tarafından işlenemeyeceği, sanıkların bu suçun faili olamayacağı, ancak azmettiren veya yardım eden sıfatıyla suça iştirak edebileceği nazara alındığında Valilik tarafından ihale komisyonu üyeleri hakkında Cumhuriyet Savcılığına suç duyurusunda bulunulduğunun anlaşılması karşısında, bu suç duyurusu sonucunun araştırılması, dava açıldığının tespiti halinde derdest ise dosyaların birleştirilmesi, kesinleşmesi durumunda ise dosyanın aslının ya da onaylı suretinin getirtilmesinden sonra sonucuna göre sanıkların hukuki durumunun tayin ve takdiri gerekir." Bkz. Yargitay 5. CD , 5.5.2016, E. 2014/2923, K. 2016/4679.

43 İNCE TUNÇER, Yalan Tanıklık Suçu, s.186.

44 İNCE TUNÇER, Yalan Tanıklık Suçu, s.188. 
durumda da tek bir fiille birden çok suç işlenmektedir. Tek fiille ortaya çıkan birden fazla suçun aynı olması halinde aynı nevi'den fikri içtima; farklı olması halinde de farklı nev'iden fikri içtima söz konusu olmaktadır. Zincirleme suç halinde de birden fazla fiil ve suç bulunmaktadır.

Tanık bilgisine başvurulan olayla ilgili olarak binden fazla noktada gerçeğe aykırı beyanda bulunmuş olabilir ki bu halde tek bir yalan tanıklık suçu oluşacaktır. Tanık soruşturma ve kovuşturma aşamalarında devam ederek yalan beyan vermiş ise bu durumda da tek bir suçtan bahsedilmelidir. Fakat tanık birden fazla maddi vakıa hakkında yalan beyanda bulunuyor ise zincirleme suç hükümlerinin uygulanması gerekir. Tanık her seferinde kişileri ve olayları farklılaştırarak gerçeğe aykırı konuşuyorsa bu durumda da binden fazla suç işlendiğinin kabulü gerekmektedir. Bu noktada maddi fiil ile hukuki fiilin birbirlerinden farklı olabileceği ve sayılarının da eşleşmeyebileceği gözden kaçırılmamalıdır.

\section{ETKINN PIŞMANLIK}

Öğretide etkin pişmanlık, "Suçun bütün unsurlarıyla tamamlanmasından sonra failin yaptığı pişmanlık gösteren hareketler" ${ }^{45}$ şeklinde tanımlanmış olmakla birlikte "suçun tamamlanmasından sonra failin gönüllü olarak neticeyi telafi etmeye yönelik gerçekleştirdiği davranışlardır" ${ }^{46}$ şeklinde de tanımlanmaktadır. Etkin pişmanlığın kişinin kendi çabalarıyla suçun tamamlanmasını veya neticenin gerçekleşmesini önlemek şeklinde tanımlanan TCK'nın 36. maddesinde düzenlenen "gönüllü vazgeçme"den farklı olduğu unutulmamalıdır. Etkin pişmanlık durumunun suçun işlenmesinden sonra ortaya çıkması nedeniyle suçun unsurlarının oluşumuna etkisi yoktur ${ }^{47}$.

Diğer bir deyişle etkin pişmanlık suçun haksızlık tanımını ve suç olma vasfinı etkilememektedir. Bunun yanında failin kusuruna da etkisi yoktur. Dolayısıyla faile tamamen ceza verilmemesi sonucunu doğuracak şekilde etkin pişmanlığın bulunması durumunda dahi verilmesi gereken karar beraat değil ceza verilmesine yer olmadığı kararıdır.

Yalan tanıklık, "gerçeğe aykırı tanıklık yapmak ve bildiğini saklamak" şeklinde tanımlanabilirse, bu suçun etkin pişmanlığ da "gerçeğin

45 HAKERİ, Hakan, Ceza Hukuku Genel Hükümler, Adalet Yayınevi, 23. Bask1, Ankara 2020, s.660.

46 KOCA/ÜZÜLMEZ, s.415.

47 Bkz. KEKLİK, Ramazan, 5237 sayılı Türk Ceza Kanununda Etkin Pişmanlık, Adalet Yayınevi, Ankara 2016. 
söylenmesi-gerçeğe dönülmesi” şeklinde tanımlanabilir. Açık bir ikrar olmasa dahi etkin pişmanlık özü itibariyle kişinin gerçeği söylemesiyle önceki beyanlarında yalan söylediğini veya gerçeği gizlediğini belirtmesi demektir ${ }^{48}$.

Etkin pişmanlık hali için kişinin önceki ifadelerinden dönmesi kafidir, samimiyetle yalan söylemekten ya da gerçeği gizlemekten pişman olduğunu söylemesine gerek yoktur. Yani ifadeleri arasındaki çelişkiler sorulduğunda misal olarak "heyecanlanmıştım, kendimde değildim, sonradan aklım başıma geldi” şeklindeki açıklamalar önceki söylediklerinden döndüğünü göstermeye yeterlidir. Nitekim Yargıtay benzer doğrultuda kararlar vermektedir $^{49}$. Hatta kişinin tanıklık yaparken bildiği gerçeği saklama halinde de bu durumun oluşabileceğine dair kararlar verilmektedir ${ }^{50}$.

TCK'nın 274. maddesinde düzenlenen etkin pişmanlık hükümlerinin uygulanması bakımından iki ölçüt kullanılmıştır. Bunlar aleyhinde yalan tanıklıkta bulunulan kimse bakımından ortaya çıkan sonuçlar ve gerçeğin söylendiği an itibariyle yargılamanın gelmiş olduğu safhadır. Aleyhine tanıklık yapılan kimse bakımından ortaya çıkan sonuçlar ağırlaştıkça ve muhakeme aşamaları ilerledikçe fail hakkında hükmedilecek ceza indirimi oranı azalmaktadır.

48 "Sanı̆̆ın, yalan tanıklıktan hakkında dava açıldıktan sonra duruşma sırasında söylediği "suçumu kabul ediyorum, ancak lehine tanıklık yaptığım insanların yanında kaldığım için onlara muhtaç olduğumdan işittiğim şeyleri söyleyemedim" diyerek gerçeğe döndüğünün anlaşılması karşısında;765 sayılı TCY.nın 289/2. maddesinde ön görülen yalan tanıklıktan dönmeye ilişkin hükümlerin uygulanıp uygulanmayacağı tartışılmadan, yetersiz gerekçe ile hüküm kurulması..." Bkz. Yargıtay 4. CD, 18.6.2008, E. 2006/10767 sayılı karar.

49 Yargitay 4. Ceza Dairesi'nin 06.12.2011, E. 2009/20331, K. 2011/23236 say1lı kararında "sanık E.D.nin aşamalarda olay günü sürücü belgesiz kullandığı araç ile tek taraflı yaralamalı trafik kazası yapması nedeniyle kendisini ceza almaktan kurtarmak amacı ile suçu üstlenen A.U.nun "suç üstlenmek" ve kendisinin de sürücü belgesiz araç kullanmak suçlarından yargılandıkları davalarda aracı A.U.nun kullandığı yönünde yalan tanıklık yapmaları konusunda diğer sanıkları azmettirdiğini belirtmesi ve sanıklar Y.O. ve M.G.nin de yalan tanıklık yaptıklarını söyleyerek gerçeği açıklamalarının karşısında sanıklar hakkında 5237 sayıl TCK'nun 274/2-3 maddelerinde düzenlenen etkin pişmanlık hükmünün uygulanma olanağının tartışılmaması bozmayı gerektirmektedir." denilmiştir.

50 Yargitay 4. Ceza Dairesi'nin 21.03.2011, 2009/2368, 2011/3505 sayılı kararında "Sanı̆̆ın mahkemede tanık sıfatıyla ifade verirken, köyde şahit olduğu kavga olayını hatırlı kişilerin aracı olması ve tarafların barışacağı gerekçesiyle görmediğini söylemesine karşın, sonraki ifadesinde kavgay gördügüüü söyleyerek gördüklerini anlatması biçimindeki eyleminde TCK'nın 272, 274/1. maddelerinin uygulanması gerektiğinin gözetilmemesi bozmayı gerektirmiştir." denilmişstir. 
Etkin pişmanlık hükümlerine ilişkin olarak tartışmalı noktalardan biri de gerçeğe aykırı tanıklığın lehe yapılması durumunda, söz konusu etkin pişmanlık hükümlerinin uygulanıp uygulanmayacağıdır. Yargıtay'ın uygulamalarında farklılıklar gözlenmektedir. Bir kısım kararlarında etkin pişmanlık hükümleri yalnızca failin aleyhe tanıklık yaptığı hallere mahsus olarak uygulanabilir; lehe yalan tanıklık yapılması durumunda, 274. madde hükmünün uygulanamayacağı yönündedir ${ }^{51}$. Nitekim Yargitay Ceza Genel Kurulu'nun üst üste verilen kararlarında da etkin pişmanlık hükümlerinin aleyhe tanıklık hallerinde uygulanacağ 1 , lehe yapılan yalan tanıklıktan dönülmesi halinde etkin pişmanlık hükümlerinin uygulanmayacağını karara bağlamıştır ${ }^{52}$.

Ceza yargılamasının asıl amacının maddi gerçeğe ulaşarak adaletin tesis edilmesi ve kişinin adil yargılanmasını sağlamak olduğuna göre lehe yalan tanıklık yapılması halinde de etkin pişmanlık hükümlerinin uygulanması kanaatimizce de gereklidir.

TCK'nın 272. maddesinin 1 ila 3. fikralarında yer alan düzenlemeler dikkate alındığında korunan değerin maddi gerçek olduğu sonucuna varılmaktadır. Maddi gerçeğin tespit edilerek korunduğu bir durumda yalan olduğu ortaya çıkan tanık beyanının lehe ya da aleyhe olması etkin pişmanlığın hayat bulması için önemli olmamalı, aleyhe yalan tanıklığın derecesine göre ceza tespitine gidilmelidir. Zira aleyhe beyanda bulunan tanık etkin pişmanlıktan yararlanırken, lehe beyanda bulunan tanığın etkin pişmanlıktan yararlanmadan daha fazla cezaya çarptırılmasında kamu yararı görülmemelidir. Çünkü bu durumun lehe yalan beyanda bulunan tanık bakımından aleyhe sonuç doğuracağı ve korunan hukuki menfaat esas alındığında Anayasa'nın eşitlik ilkesine de aykırı olacağı kanaatindeyiz.

Yargıtay'da bizim de içinde yer aldığımız bu görüşü savunanlara göre hükümden önce ya da ceza davasında mahkûmiyet kararı kesinleşmeden önce gerçeği söylemesi halinde, yalan beyanın lehe ya da aleyhe olduğuna bakılmaksızın fail, etkin pişmanlık hükmünden yararlanmalıdır. TCK'nın 274. maddede geçen "aleyhine tanıklık yapılan kişi”" ifadesi, suçun neticesi

51 "Aleyhine tanıklık yapılan kişi hakkında bir hak kısıtlaması veya yoksunluğunu sonuçlayacak nitelikte karar verilmeden veya hükümden önce ya da aleyhine tanıklık yapılan kişi hakkında mahkûmiyet kararı kesinleşmeden önce gerçeğin söylenmesi halinde TCK'nın 274. maddesinde düzenlenen etkin pişmanlık hükmünün uygulanabileceği, lehe yalan tanıklık yapılıp da gerçeğe dönülmesi halinde anılan madde hükmünün uygulanamayacağı...” Bkz. Yargitay 9. CD, 19.11.2014, E. 2014/6798, K. 2014/11701.

52 Bkz. Yargitay CGK, E.2014/9-428, K.2018/8 say1l1, E.2015/177, K.2018/205 say1l1, E.2015/187- K. 2018/206 say1lı kararlar1. 
sebebiyle ağırlaşmış hallerinin düzenlendiği TCK'nın 272. maddenin 4 ilâ 8 . fikraları ile atıflı düşünülmelidir. TCK'nın 272. maddenin 4 ilâ 8 . fikralarında kullanılan aleyhinde tanıklıkta bulunulan kişi ifadesiyle, yalan tanıklık suçu nedeniyle mağdur olan kişiler kastedilmiştir. Ağır sonuçların failin tanıklığı nedeniyle ortaya çıkmış olması gerektiği için böyle bir ifade kullanıldığı yani yalan tanıklık suçunun ağır neticeleri, aleyhinde gerçeğe aykırı tanıklıkta bulunulan kişiyle ilgili olarak ortaya çıkmaktadır. TCK'nın 274. maddesinde ise failin etkin pişmanlıktan yararlanabileceği zaman dilimi ifade edilmiştir. Düzenleme ile aşamalı bir biçimde aleyhinde tanıklıkta bulunulan kişi hakkında verilen kararın niteliğine göre etkin pişmanlık neticesinde yapılacak indirim oranı belirlenmiştir.

Nitekim Yargitay Ceza Genel Kurulu'nun 2018/9-298 esas say1lı 03.12.2020 tarihli kararında da bu husus tartışılmış olup, lehe yalan tanıklık suçunu işleyen kişinin de etkin pişmanlık hükümlerinden yararlanmasına hükmolunmuştur. Madde düzenlemesi ile korunan hukuki menfaat esas alındığında maddenin uygulamasında Anayasanın eşitlik ilkesine aykırı bir durumun doğmasına sebep olacağından lehe tanıklık dahi olsa yalan tanıklıktan dönülmesi halinde etkin pişmanlık hükümleri uygulanmalıdır.

Fail, soruşturma evresinde de söz konusu etkin pişmanlık hükmünden yararlanabilir. Soruşturma evresinde failin, aleyhine tanıklık yaptığı kişi hakkında bir hak kısıtlamasını veya yoksunluğunu sonuçlayacak nitelikte karar verilmeden önce gerçeğe dönmesi halinde Cumhuriyet savcısı, kamu davasını açmada takdir yetkisini kullanarak kovuşturmaya yer olmadığ karar1 verebilir (CMK m. 171). Ancak belirtmek gerekir ki, 274. maddenin 2. ve 3. fikraları bakımından Cumhuriyet savcısının böyle bir takdir hakkı bulunmamaktadır.

Cezanın tamamen ortadan kalkmasını gerektiren etkin pişmanlık hali TCK'nın 274. maddesinin ilk fikrasında düzenlenmiştir. Buna göre "Aleyhine tanıklık yapılan kişi hakkında bir hak kısıtlamasını veya yoksunluğunu sonuçlayacak nitelikte karar verilmeden veya hükümden önce gerçeğin söylenmesi halinde cezaya" hükmolunmayacaktır. Bu hüküm lehe tanıklık yapan yalan tanıklar hakkında da uygulanmalı, aleyhe tanıklığın ise hak kısıtlaması veya yoksunluğunu doğurmamış olması halinde ve hüküm verilmeden önce pişmanlık gösterilerek gerçeğe dönülmesi durumunda uygulanmalıdır. Burada Kanun koyucunun aradığı gerçeğin hüküm ne olursa olsun öncesinde açığa çıkarılmasıdır. Çünkü hükümle yalan beyana itibar edilerek karar verilmiş olacaktır. Nitekim hüküm verildikten sonra ve fakat kesinleşmeden önce yalan beyandan dönülmesi halinde TCK'nın 274maddesinin 3. fikrasındaki etkin pişmanlık hali söz konusu olacaktır. 
TCK'nın 274. maddesinin 1. fikrasındaki durumda soruşturma aşamasında ise Takipsizlik Kararı, kovuşturma aşamasında ise Ceza Verilmesine Yer Olmadığına Kararı verilecektir.

TCK'nın 274. maddesinin 2. fikrasında “Aleyhine tanıklık yapılan kişi hakkında bir hak kısıtlamasını veya yoksunluğunu sonuçlayacak nitelikte karar verildikten sonra ve fakat hükümden önce gerçeğin söylenmesi halinde" yalan tanıklık suçunun cezasında indirim yapılabileceği düzenlenmiştir. Burada da lehe tanıkla beraber aleyhine tanıklık yapan failin fiilinin ikinci aşaması düşünülmelidir. Hakim karar gerekçesini de göstererek yalan tanıklık suçunun cezasında $1 / 2$ ila $2 / 3$ oranında indirim yapabilecektir.

TCK'nın 274. maddesinin 3. fikrasinda da "Aleyhine tanılık yapılan kişi hakkında verilen mahkumiyet kararı kesinleşmeden önce gerçeğin söylenmesi halinde verilecek cezanın yarısından üçte birine kadarının" indirilebileceği düzenlenmiştir. Yani hakim kararının gerekçesini göstererek yalan tanıklık suçunun cezasında asgari $1 / 3$, azami $1 / 2$ oranda indirim yapabilecektir.

Etkin pişmanlık gösteren kişinin bu eylemindeki gayret ve samimiyeti ile maddi gerçeğin ortaya çıkmasına ve dolayısıyla adaletin tecellisine katkısı gibi kriterler göz önünde tutularak cezada indirim yapılıp yapılmayacağına ve yapılacak ise indirim oranının takdirine karar verilecektir. Takdir hakkı hakimindir.

\section{KAYNAKÇA}

ARTUK, Mehmet Emin/GÖKCEN, Ahmet/YENIDÜNYA, Caner, Ceza Hukuku Özel Hükümler, Adalet Yayınevi, Ankara 2014.

ARTUK, Mehmet Emin/GÖKCEN, Ahmet/YENIDÜNYA, Caner, Ceza Hukuku Genel Hükümler, Adalet Yayınevi, Ankara 2014.

CENTEL, Nur/ZAFER, Hamide, Ceza Muhakemesi Hukuku, Beta Yayıncılık, 16. Bask1, İstanbul 2019.

FEYZIOĞLU, Metin, Ceza Muhakemesi Hukukunda Tanıklık, US-A Yayıncılık, Ankara 1996.

GÖKTÜRK, Neslihan, "Yalan Tanıklık Suçu”, Gazi Üniversitesi Hukuk Fakültesi Dergisi, C. XX, Y. 2016, S.1, ss. 347-409.

HAFIZOĞULLARI, Zeki, "Kusurluluğu Kaldıran Bir Neden Olarak Ceza Hukukunda İstenemezlik Illkesi”, Ankara Üniversitesi Hukuk Fakültesi Dergisi, Y11: 2008, Cilt: 57, Say1: 3, s. 338-360.

HAFIZOĞULLARI, Zeki/ÖZEN, Muharrem, Türk Ceza Hukuku Özel Hükümler Millete ve Devlete Karşı Suçlar, US-A Yayıncılık, Ankara 2016. 
HAKERİ, Hakan, Ceza Hukuku Genel Hükümler, Adalet Yayınevi, 23. Bask1, Ankara 2020.

İÇEL, Kayıhan, Ceza Hukuku Genel Hükümler, Beta Yayıncılık, Ankara 2018.

İNCE TUNÇER, Asuman, Yalan Tanıklı Suçu, Hacettepe Üniversitesi Sosyal Bilimler Enstitüsü Kamu Hukuku Anabilim Dalı Doktora Tezi, Ankara 2019.

KEKLIK, Ramazan, 5237 sayılı Türk Ceza Kanununda Etkin Pişmanlık, Adalet Yayınevi, Ankara 2016.

KOCA, Mahmut/ÜZÜLMEZ, İlhan, Türk Ceza Hukuku Özel Hükümler, Adalet Yayınevi, 7. Bask1, Ankara 2020.

ÖZBEK, Veli Özer/DOĞAN, Koray/BACAKSIZ, Pınar/TEPE, İlker, Ceza Muhakemesi Hukuku, Seçkin Yayınevi, Ankara 2020.

ÖZBEK, Veli Özer/DOĞAN, Koray/BACAKSIZ, Pınar/TEPE, İlker, Türk Ceza Hukuku Genel Hükümler, Seçkin Yayıncılık, 11. Baskı, Ankara 2020.

ÖZBEK, Veli Özer/DOĞAN, Koray/BACAKSIZ, Pınar, Türk Ceza Hukuku Özel Hükümler, Seçkin Yayıncılık, Ankara 2020.

ÖZGENÇ, İzzet, Suça İştirak, İBB Hukuk Müşavirliği, İstanbul 1996.

SOYASLAN, Doğan, Ceza Hukuku Özel Hükümler, Yetkin Yayınevi, 11. Bask1, Ankara 2016.

ŞAHIN, Cumhur / GÖKTÜRK, Neslihan, Ceza Muhakemesi Hukuku, Seçkin Yayınevi, 5. Baskı, Ankara 2020.

TEZCAN, Durmuş/ERDEM, Mustafa Ruhan/ÖNOK, Murat, Ceza Özel Hukuku, Seçkin Yayınevi, Ankara 2020.

TÖNGÜR, Ali Rıza, "Yargıtay Kararları Doğrultusunda İştirak Türü Olarak Dolayl Faillik ve Azmettirme", Ceza Hukuku Dergisi, S. 28, Y. 2015, ss. 223259.

ÜNVER, Yener, Adliyeye Karşı Suçlar, Seçkin Yayıncılık, 3. Baskı, Ankara 2013.

ÜNVER, Yener/HAKERİ, Hakan, Ceza Muhakemesi Hukuku, Adalet Yayınevi, 17. Bask1, Ankara 2020.

YAŞAR, Osman / GÖKCAN, Hasan Tahsin / ARTUÇ, Mustafa, YorumluUygulamalı Türk Ceza Kanunu, C. 6, 2. Baskı, Adalet Yayınevi, Ankara 2014. 